\title{
MANAGEMEN LABORATORIUM SEBAGAI PENDUKUNG KEGIATAN BELAR MENGAJAR IPA BIOLOGI
}

\author{
Nuri Dewi Muldayanti ${ }^{1}$, Arif Didik Kurniawan ${ }^{2}$ \\ ${ }^{1,2}$ Program Studi Pendidikan Biologi, Universitas Muhammadiyah Pontianak \\ e-mail: nuri.dewi@unmuhpnk.ac.id, arif.didik@unmuhpnk.ac.id
}

\begin{abstract}
Abstrak
Manajemen laboratorium merupakan keterampilan yang harus dimiliki oleh guru laboran yang diperlukan untuk mengelola laboratorium guna mendukung pembelajaran. Tujuan kegiatan yaitu memberikan pelatihan kepada guru dan laboran di sekolah menengah. Metode dalam melaksanakan kegiatan secara online dengan metode ceramah dan tanya jawab antara pemateri dan peserta kegiatan. Sasaran kegiatan pengabdian ini yaitu guru IPA Biologi di tingkat SMP dan SMA. Hasil pengabdian yaitu $52,6 \%$ peserta menyatakan sangat setuju dan $47,4 \%$ peserta menyatakan setuju bahwa kegiatan tentang manajemen laboratorium sesuai dengan kebutuhan. Untuk 55\% peserta menyatakan sangat setuju dan $45 \%$ peserta menyatakan setuju bahwa penyampaian materi pada kegiatan manajemen laboratorium dapat dipahami oleh peserta. Untuk 85\% peserta menyatakan sangat setuju dan $15 \%$ peserta menyatakan setuju bahwa hasil kegiatan pelatihan dapat diimplementasikan pada saat di sekolah. Kesimpulan dari kegiatan ini yaitu kegiatan pengabdian ini sangat diperlukan oleh guru terutama kepala laboratorium dan laboran dalam meningkatkan kompetensinya.
\end{abstract}

Kata kunci: managemen, laboratorium, pembelajaran

\begin{abstract}
Laboratory management is a skill that a laboratory assistant must have to manage a laboratory to support learning. The purpose of the activity is to provide training to teachers and laboratory assistants in secondary schools. Methods in carrying out online activities with lectures method and questions and answers between the presenters and activity participants. The results of community service, namely $52.6 \%$ of participants stated that they strongly agreed and $47.4 \%$ agreed that activities regarding laboratory management were in accordance with their needs. $55 \%$ of participants stated that they strongly agreed and $45 \%$ agreed that the delivery of material in laboratory management activities could be understood by the participants. $85 \%$ of participants stated that they strongly agreed and $15 \%$ agreed that the results of training activities could be implemented at school. The conclusion of this activity is that this service activity is needed by teachers, especially the head of laboratories and laboratory assistants in increasing their competence.
\end{abstract}

Keywords : management, laboratory, learning 


\section{PENDAHULUAN}

Mata pelajaran IPA merupakan mata pelajaran yang pada saat proses pembelajaranya melakukan kegiatan praktikum. Untuk itu diperlukan adanya sarana prasarana yang mampu mendukung terlaksananya kegiatan praktikum tersebut. Salah satunya yaitu harus tersedianya sarana prasarana laboratorium sekolah sebagai penunjang kegiatan belajar mengajar IPA. Menurut Kistinnah, dkk (2011) menjelaskan fenomena-fenomena yang berkaitan dengan ilmu sains dibutuhkan fasilitas untuk menunjang pembelajaran, seperti laboratorium. Dalam pendidikan sains kegiatan laboratorium merupakan bagian integral dari kegiatan belajar mengajar (Sari, N: 2014).

Laboratorium merupakan salah satu sarana prasarana yang harus dimiliki oleh sekolahan dalam rangka menunjang kegiatan belajar mengajar. Karena dengan adanya laboratorium mampu menunjang keberhasilan pembelajaran, baik pada pendidikan menengah maupun pendidikan tinggi. Peraturan Menteri Pendidikan Nasional No. 24 Tahun 2007 tentang Standar Sarana Prasarana menyatakan bahwa salah satu sarana yang dibutuhkan dan harus dimiliki oleh setiap satuan pendidikan untuk mendukung keberhasilan kegitan pengamatan dan percobaan yaitu tersedianya laboratorium.

$$
\text { Menurut Tone (2017) }
$$

laboratorium merupakan ruangan baik tertutup maupun terbuka yang dirancang sesuai dengan kebutuhan untuk melakukan aktivitas yang berkaitan dengan fungsi-fungsi pendidikan, penelitian dan pengabdian kepada masyarakat. Dalam pemanfaatan laboratorium berjalan dengan baik, maka laboratorium tersebut harus dikelola dengan baik, dan pengelolaan laboratorium yang baik harus didukung dengan manajemen laboratorium yang baik juga. Menurut Adriani (2016) semakin bagus pelaksanaan manajemen laboratorium semakin meningkat juga kompetensi dari sumber daya manusia yang ada. Namun pada kenyataanya, masih terdapat sekolahan yang sudah memiliki laboratorium tetapi dalam segi manajemennya masih banyak yang masih belum maksimal. Untuk itu diperlukan kegiatan atau pelatihan bagi guru, laboran dan kepala laboratorium guna meningkatkan kompetensi dalam memanajemen laboratorium.

$$
\text { Manajemen laboratorium }
$$

merupakan suatu usaha untuk mengelola laboratorium agar memiliki tatakelola yang baik. Pengelolaan laboratorium dapat dikelola dengan baik, sangat ditentukan oleh beberapa faktor yang saling berkaitan satu dengan yang lainya. Beberapa alat-alat laboratorium yang canggih, dengan staf professional yang terampil belum tentu dapat beroperasi dengan baik, jika tidak didukung oleh adanya manajemen laboratorium yang baik. Oleh karena itu, manajemen laboratorium adalah suatu bagian yang tidak dapat dipisahkan dari kegiatan laboratorium. Suatu manajemen laboratorium yang baik memiiki system organisasi yang baik, uraian kerja (job description) yang jelas, pemanfaatan fasilitas yang efektif, efisien, disiplin, dan administrasi laboratorium yang baik pula (Sari: 2013). 


\section{METODE}

Kegiatan Pengabdian ini di laksanakan di Program Studi Pendidikan Biologi UM Pontianak yang beralamat di Jl. Ahmad Yani No. 111 Pontianak Tenggara. Kegiatan dilaksanakan secara online dengan menggunakan aplikasi Zoom meeting Pelaksanaan kegiatan pada hari Kamis dari jam 09.00 hingga 11.30 WIB.

Adapun alur pelaksanaan kegiatan PKM Bimbingan Teknis Managemen Laboratorium Sebagai Pendukung Kegiatan Belar Mengajar IPA Biologi dapat dilihat pada gambar alur berikut:

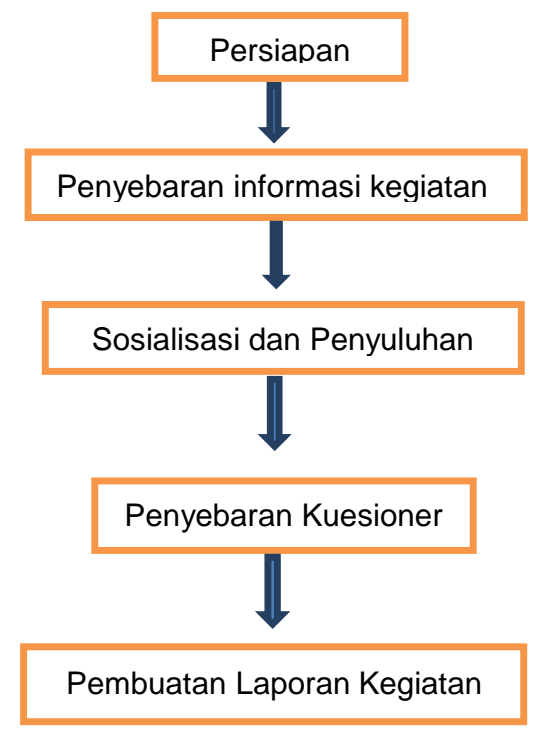

Gambar 1. Alur Pelaksanaan Kegiatan PKM

Prosedur yang pertama kali yang dilakukan yaitu persiapan. Pada tahap ini pengabdi menyiapkan semua perangkat yang dibutuhkan pada saat kegiatan berlangsung, mulai dari tempat pelaksanaan, brosur kegiatan, serta mekanisme online seperti apa yang akan dilaksanakan. Selain itu, pada kegiatan ini juga menentukan peserta yang akan di mengikuti kegiatan yaitu guru SMP dan SMA yang mengajar IPA Biologi atau guru lain yang menjadi kepala laboratorium atau laboran. Tahap yang kedua yaitu menyebarkan informasi kegiatan kepada guru-guru yang sudah menjadi sasaran kegiatan dengan melalui WA dan sosial media lainya. Peserta yang ditargetkan untuk mengikuti kegiatan yaitu 30 sampai dengan 40 orang guru. Pada tahap ini juga menyebarkan surat undangan resmi kepada sekolah-sekolah yang berada disekitar tempat pengabdian untuk mengikuti kegiatan.

Untuk tahap yang ketiga yaitu pelaksanaan kegiatan sosialisasi dan penyuluhan. Kegiatan ini dilaksanakan secara daring atau online dengan aplikasi zoom meeting. Kegiatan dilakukan dengan metode ceramah dan Tanya jawab antara peserta dan pengabdi tentang tema yang sudah ditentukan dan sebagai upaya untuk mengetahui tingkat pemahaman para peserta kegiatan. Pada tahap keempat yaitu penyebaran kuesioner kepada peserta kegiatan. Kuesioner ini digunakan untuk mengukur keberhasilan atau untuk menyaring respon peserta terhadap kegiatan yang telah dilaksanakan. Tahap yang kelima yaitu pembeuatan laporan. Pembuatan laporan ini difungsikan untuk melaporkan pelaksanaan kegiatan kepada penyandang dana yaitu UM Pontianak. 


\section{HASIL DAN PEMBAHASAN}

Kegiatan pengabdian tentang bimbingan teknis managemen laboratorium dalam menunjang pembelajaran dalam mendukung pembelajaran IPA Biologi dilaksanakan secara online melalui aplikasi zoom. Proses pengabdian ini dilaksanakan secara online mengingat kondisi di Provinsi Kalimantan Barat masih terutama wilayah Kota Pontianak masih dalam kondisi terkena wabah virus corona. Kegiatan pengabdian ini dilaksanakan pada hari Kamis tanggal 11 Juni 2020 di Program Studi Pendidikan Biologi Fakultas Keguruan dan IImu Pendidikan Universitas Muhammadiyah Pontianak dengan diikuti 28 guru SMP dan SMA yang tersebar di beberapa kabupaten di Provinsi Kalimantan Barat.

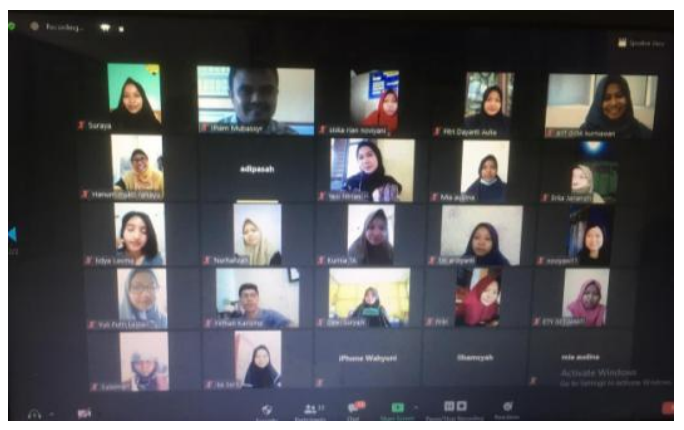

Gambar. 2 Proses kegiatan pelatihan managemen laboratorium

Setelah kegiatan pengabdian selesai dilaksanakan, pengabdi melakukan penyebaran angket melalui google form terkait dengan kegiatan pengabdian yang dilakukan. Dari hasil google form yang di berikan ke peserta kegiatan pengabdian diperoleh hasil, sebagai berikut (tabel 1).
Kegiatan pengabdian managemen laboratorium diikuti 28 peserta dari beberapa sekolahan. Kegiatan pengabdian dilaksanakan dengan menggunakan aplikasi zoom dikarenakan kondisi wilayah Kalimantan Barat dan sekitarnya masih dilanda wabah pandemi virus corona. Kegiatan pengabdian dapat berjalan dengan lancar dengan sistem tanya jawab antara peserta dan pemateri terhadap materi yang disampaikan pada saat kegiatan berlangsung.

Kegiatan pengabdian tentang tatakelola managemen laboratoium di sekolahan merupakan kegiatan pengabdian yang ditujukan kepada guru IPA yang sekolahanya sudah memiliki fasilitas laboratorium guna menunjang kegiatan pembelajaran disekolah ataupun guru yang sekolahanya belum memiliki fasilitas laboratorium. Kegiatan pengabdian manajemen laboratorium ini dalam rangka agar sekolahan yang memiliki fasilitas laboratorium mampu memberikan pelayanan yang baik dari sisi pelayanan administrasi maupun pelayanan sarana prasarana pada saat kegiatan praktikum berlangsung. Menurut Arisal Nurhadi (2018) managemen laboratorium suatu proses dalam perancanaan, pengorganisasian, penggerakan, dan pengendalian peralatan dan perlengkapan yang secara langsung dan secara tidak langsung dipergunakan untuk menunjang jalannya proses pendidikan untuk pengajaran, penelitian, pengamatan, pelatihan dan pengujian ilmiah.

Peraturan Menteri Pendidikan Nasional No. 24 Tahun 2007 tentang Standar Sarana Prasarana menyatakan 
bahwa salah satu fasilitas yang diperlukan oleh setiap sekolahan untuk mendukung keberhasilan kegitan pembelajaran, pengamatan dan percobaan yaitu tersedianya sarana laboratorium. Ini juga didukung oleh Peraturan Menteri Pendidikan dan Kebudayaan No. 32 Tahun 2013 tentang Standar Nasional Pendidikan, di sini dijelaskan bahwa laboratorium merupakan salah satu standar sarana yang dibutuhkan untuk menunjang proses pembelajaran dalam rangka memenuhi capaian pembelajaran lulusan. Menurut Annisa Ratna Sari (2013) menjelaskan bahwa manajemen laboratorium merupakan suatu bagian yang tidak dapat dipisahkan dari kegiatan laboratorium. Untuk itu, penting bagi guru IPA memiliki pemahaman dan pengetahuan terkait dengan pengelolaan laboratorium.

Berdasarkan hasil kuesioner yang di berikan kepada peserta kegiatan pengabdian terkait dengan kesesuain kegiatan pengabdian dengan kebutuhan peserta, dapat dilihat pada gambar diagram di bawah ini:

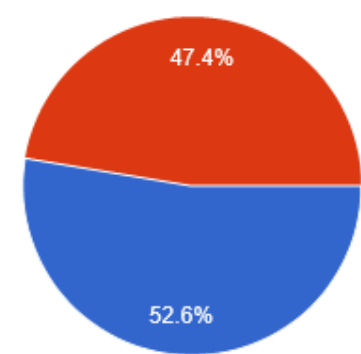

Gambar 3. Diagram kesesuaian kegiatan PKM dengan kebutuhan peserta

Berdasarkan dari gambar diagram di atas menunjukan hasil bahwa 52,6 \% peserta kegiatan menyatakan sangat setuju dan $47,4 \%$ peserta kegiatan menyatakan setuju bahwa kegiatan pengabdian tentang manajemen laboratorium sesuai dengan kebutuhan peserta. Hal ini dikarenakan guru jarang mendapatkan pelatihan dan pemahaman terkait dengan bagaimana cara mengelola laboratorium yang baik. Menurut Asy'ari, Rusman, dan Riyana (2020) menjelaskan bahwa program pelatihan bertujuan untuk meningkatkan kemampuan teknis, teoritis, konseptual, dan moral karyawan agar karyawan lebih baik dalam melaksanakan tugasnya dan memperoleh hasil yang optiomal. Menurut Lasia, dkk (2020) menjelaskan dengan adanya kegiatan pelatihan memberikan peningkatan pengetahuan atau informasi kepada para peserta kegiatan. Selain itu, peserta kegiatan pengabdian juga memberikan masukan terkait dengan kegiatan pengabdian selanjutnya yaitu dapat memberikan pelatihan praktikum sederhana bagi sekolahan yang belum memiliki fasilitas laboratorium atau sekolahan yang laboratoriumnya belum memiliki fasilitas yang memadai. Praktikum sederhana ini akan membantu guru dan siswa dalam melaksanakan proses pembelajaran guna mencapai tujuan pembelajaran.

Berdasarkan hasil kuesioner yang di berikan kepada peserta kegiatan pengabdian terkait dengan penyampaian materi kegiatan pengabdian, dapat dilihat pada gambar diagram di bawah ini: 


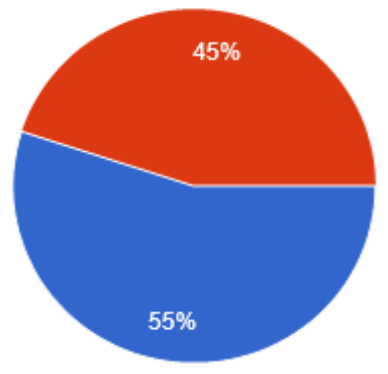

Gambar 4. Diagram tentang pemahaman materi yang disampaikan

Berdasarkan gambar diagaram di atas menjelaskan bahwa 55\% peserta kegiatan menyatakan sangat setuju dan $45 \%$ peserta kegiatan menyatakan setuju bahwa penyampaian materi pada kegiatan pengabdian tentang manajemen laboratorium dapat dipahami oleh peserta. Kegiatan pengabdian tentang managemen laboratorium dilaksanakan dengan menggunakan media power point yang disertai dengan gambargambar yang berkaitan dengan pengelolaan laboratorium menjadikan materi mudah untuk disampaikan dan mudah dipahami oleh peserta kegiatan. Selain itu, sebelum kegiatan dimulai panitia kegiatan pengabdian mengirimkan materi kegiatan kepada seluruh peserta sehingga peserta dapat membaca materi pengabdian sebagai pengetahuan awal peserta sebelum mengikuti kegiatan. Menurut Adriani (2016) menjelaskan bahwa perlu adanya seminar atau pelatihan bagi kepala sekolah atau laboran dalam meningkatkan kompetensi atau pemahaman dalam mengelola laboratorium.

Berdasarkan hasil kuesioner yang di berikan kepada peserta kegiatan pengabdian terkait dengan dapat mengimplementasikan setelah kegiatan pengabdian, dapat dilihat pada gambar diagram di bawah ini:

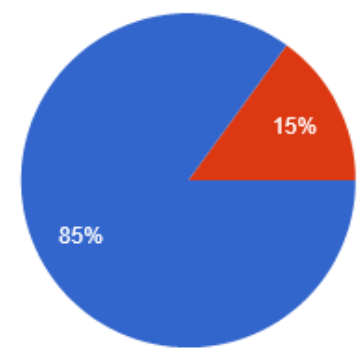

Gambar 5. Diagram Tentang Implementasi Hasil Kegiatan

Berdasarkan gambar diagram di atas menjelaskan bahwa $85 \%$ peserta kegiatan menyatakan sangat setuju dan $15 \%$ peserta kegiatan menyatakan setuju bahwa hasil kegiatan pelatihan dapat diimplementasikan oleh peserta pengabdian pada saat di sekolah. Dalam pengimplementasian pengelolaan laboratorium terdapat empat tahap yaitu: 1) Tahap Perencanaan yaitu merencanaan alat dan bahan, administrasi, dan lain sebagainya yang diperlukan meyesuaikan dengan kebutuhan parktikum yang akan dilaksanakan di sekolahan. Para peserta kegiatan yang sekolahanya sudah memiliki laboratorium rata-rata sudah melaksanakan kegiatan perencanaan guna mempersiapkan kegiatan praktikum yang akan dilaksanakan selama satu tahun pelajaran, 2) Tahap Pengorganisasian, dalam melaksanakan manajemen laboratorium yang perlu adanya sistem keorganisasian yang baik juga, keberadaan struktur organisasi sangat penting, tetapi tidak akan berjalan sebuah organisasi jika yang berperan di dalam struktur tersebut tidak 
melaksanakan tugas sebagaimana mestinya (Adriani, Nina: 2016). Pada tahap ini masih banyak sekolahan menerapkan pengorganisasian laboratorium ini tidak ada laboran yang mengelola karena keterbatasan kemampuan sekolahan, hal ini menjadikan guru pengampu matapelajaran yang akan melaksanakan praktikum sebagai penanggung jawab kegiatan praktikum yang akan dilakukan, 3) Tahap Pelaksanaan, pada tahap ini peserta pengabdian yang sudah memiliki laboratorium rata-rata sudah melaksanakan proses praktikum mulai dari guru yang akan melaksanakan praktikum harus mengisi buku peminjaman alat dan bahan. Namun, peserta kegiatan pengabdian yang sekolahanya tidak memiliki laboran menjadikan proses pengecekan barang-barang yang ada di laboratirum jarang dilakukan menjadikan laboratorium tidak memiliki data alat bahan yang habis serta alat yang mengalami kerusakan. Untuk itu perlu proses pelaksanaan yang baik dalam memanfaatkan labotatorium guna menunjang proses pembelajaran (Adriani: 2016), 4) Tahap Pengawasan, pada tahap ini yaitu melakukan monitoring dang evaluasi terhadap kegiatan yang ada di laboratorium mulai dari inventaris alat dan bahan yang ada, mengecek sarana pendukung apakah dalam keadaan baik atau rusak untuk menunjang proses praktikum, serta kegiatan praktikum apa saja yang sudah dilaksanakan selama satu semester atau dalam satu tahun ajaran sehingga dapat dipertanggung jawabkan.

Tabel 1. Rekapan Hasil Kuesioner Kegiatan Pengabdian

\begin{tabular}{llcccc}
\hline No & \multicolumn{1}{c}{ Pernyataan } & $\begin{array}{c}\text { Sangat } \\
\text { Setuju } \\
(\%)\end{array}$ & $\begin{array}{c}\text { Setuju } \\
(\%)\end{array}$ & $\begin{array}{c}\text { Tidak Setuju } \\
(\%)\end{array}$ & $\begin{array}{c}\text { Sangat Tidak } \\
\text { Setuju } \\
(\%)\end{array}$ \\
\hline 1. & $\begin{array}{l}\text { Kegiatan PKM Manlab } \\
\text { sesuai } \\
\text { kebutuhan peserta }\end{array}$ & 52,6 & 47,4 & 0 & 0 \\
\hline 2. & $\begin{array}{l}\text { Materi yan } \\
\text { disampaikan jelas dan } \\
\text { mudah dipahami dapat }\end{array}$ & 55 & 45 & 0 & 0 \\
\hline 3. & $\begin{array}{l}\text { Peserta } \\
\text { mengimplementasikan } \\
\text { manlab setelah PKM }\end{array}$ & 15 & 0 & 0 \\
\hline
\end{tabular}

\section{KESIMPULAN}

Berdasarkan kegiatan manajemen laboratorium yang telah dilaksanakan bahwa kebanyakan guru sekali mendapatkan kegiatan training atau diklat tentang pelatihan pengelolaan

managemen

laboratorium guna menunjang proses pembelajaran. Pemerintah atau dinas yang terkait dapat mengadakan kegiatan training atau diklat guna meningkatkan sumber 
daya manusia terutama kepala laboratorium dan laboran agar memiliki dan meningkatkan kapasitasnya dalam mengelola laboratorium. Kegiatan pengabdian yang dilakukan sesuai dengan kebutuhan peserta dalam rangka pengelolaan laboratorium yang efektif. Peserta kegiatan memahami dengan apa yang disampaikan di dalam kegiatan pengabdian sehingga materi yang di sampaikan dapat diimplementasikan ke dalam laboratorium.

\section{DAFTAR PUSTAKA}

Adriani, N. 2016. Analisis Manajemen Laboratorium Kimia Sma Negeri di Kota Tanjungpinang Guna Meningkatkan Kompetensi Guru dan Peserta Didik. Jurnal Zarah. Vol 4 No. 1 Hal: 1-8

Asy'ari. H, Rusman. N.T dan Riyana. A. 2020. Evaluasi Program Pelatihan Guru di Pusdiklat Tenaga Teknis Pendidikan dan Keagamaan Kementerian Agama Republik Indonesia. Jurnal Studi Manajemen Pendidikan. Vol 4 No. 1 Hal: 6786

Adriani, N. 2016. Analisis Manajemen Laboratorium Kimia SMA Negeri di Kota Tanjung Pinang Guna Meningkatkan Kompetensi Guru dan Peserta Didik. Jurnal Zarah Vol. 4 No. 1 Halaman: 1-8

Kistinnah, dkk. 2011. Pengelolaan laboratorium untuk SMA/MA. Bina IImu: Surabaya

Lasia, K.I, Budiana, K.I dan Widiasih, N.N. 2020. Peningkatan Keselamatan Kerja Di Laboratorium Melalui Pelatihan Penggunaan Bahan Berwawasan Lingkungan. Jurnal Widya Laksana. Vol. 9 No. 1 Hal: $19-29$

Sari, A. R. 2013. Manajemen Laboratorium. Makalah yang disampaikan dalam Workshop ; "How to be a Good Laboratory With a Profesional Management" di SMK N 1 Depok Sleman. Tanggal 19 Juli 2013

Sari, N. 2014. Analisis Manajemen Laboratorium Biologi Beberapa SMA Swasta di Kota Jambi. Skripsi FKIP Universitas Jambi

Tone, K. 2017. Sistem Pengelolaan Manajemen Laboratorium Komputer Jurusan Sistem Informasi UIN Alauddin Makassar. Jurnal Instek Vol. 2 No. 2 Halaman: 121-129 